\title{
“DETERMINANTS OF AUDIT DELAY IN INDONESIA COMPANIES: EMPIRICAL EVIDENCE"
}

\author{
Luki Retno Puri Rahayu \\ Universitas PGRI Madiun
}

\begin{abstract}
The purpose of this research is to examine the impact of firm size, DER, auditor opinion, anda public accounting firm sizetoward audit delay in sanctions-hit Indonesia Stock Exchange in 2013.The population of the study is a company that sanctioned the Indonesia Stock Exchange in 2013 and listed on the Indonesian Stock Exchange in the period 2012-2015.These samples wereselected by using Purposive sampling method with the total sample of 16 companies. The data analysis uses multiple regressions. The results showed that the firm size, DER, auditor opinion, and a public accounting firm sizenot affect audit delay. Partial testing, showing the firm size, DER, auditor opinion, and a public accounting firm sizenot affect audit delay.
\end{abstract}

Keywords: audit delay, firm size, DER, auditor opinion, and a public accounting firm size.

\section{Abstrak}

Penelitian ini bertujuan untuk menganalisis apakah ukuran perusahaan, DER, opini auditor, dan ukuran KAP, baik parsial maupun simultan berpengaruh terhadap audit delay pada perusahaan yang terkena sanksi Bursa Efek Indonesia pada tahun 2013.Populasi penelitian adalah perusahaan yang terkena sanksi Bursa Efek Indonesia pada tahun 2013 dan terdaftar di Bursa Efek Indonesia padaperiode 2012-2015. Pemilihan sampel menggunakan metode Purposive Sampling dengan jumlah sampel sebanyak 16 perusahaan. Analisis data menggunakan regresiberganda. Hasil penelitian menunjukkan bahwa ukuran perusahaan, DER, opini auditor, dan ukuran KAP bersama-sama tidak berpengaruh terhadap audit delay. Pengujian secara parsial, menunjukkan ukuran perusahaan, DER, opini auditor, dan ukuran KAP tidak berpengaruh terhadap audit delay.

Kata kunci: audit delay, ukuran perusahaan, DER, opini auditor, dan ukuran KAP.

\section{PENDAHULUAN}

Laporan keuangan merupakan suatu instrumen yang penting dan sangat bermanfaat dalam sebuah perusahaan. Suatu Informasi yang terkandung dalam laporan keuangan dapat dikatakan bermanfaat jika laporan keuangan tersebut disajikan secara akurat dan tepat waktu, yaitu tersedia saat dibutuhkan oleh para pengguna seperti yang tercantum dalam Pernyataan Standar Akuntansi Keuangan (PSAK: 2009) menerangkan bahwa suatu laporan keuangan harus memenuhi empat karakteristik kualitas yang membuat informasi laporan keuangan bermanfaat bagi sejumlah besar penggunanya. Keempat karakteristik tersebut antara lain dapat dipahami, relevan, keandalan dan dapat dibandingkan. Laporan keuangan tahunan perusahaan harus dilaporkan terutama bagi perusahaan yang sudah listing di Bursa Efek Indonesia (BEI). Berdasarkan peraturan Pasar Modal No.KEP 80/PM/1996 menyatakan bahwa seluruh perusahaan yang terdaftar dalam pasar modal wajib menyampaikan laporan keuangan tahunan yang telah diaudit kepada Bapepam selambat-lambatnya 120 hari terhitung sejak tanggal berakhirnya tahun buku. Ketertundaan perusahaan dalam menyampaikan laporan keuangan juga dapat berdampak negatif pada reaksi pasar. Semakin lama masa tunda, maka relevansi laporan keuangan semakin diragukan. Oleh sebab itu, untuk dapat digunakan sebagai 
dasar membantu dalam pengambilan suatu keputusan ekonomi dan untuk menghindari tertundanya pengambilan keputusan laporan keuangan harus disampaikan sedini mungkin.

Menurut Subekti dan Widiyanti, 2004 (dalam Puspitasari dan Nurmala, 2012) lamanya auditor dalam menyelesaikan pekerjaan auditnya merupakan salah satu sebab ketepatan perusahaan dalam mempublikasikan laporan keuangan. Lamanya waktu penyelesaian audit oleh auditor dilihat dari perbedaan waktu tanggal laporan keuangan dengan tanggal opini audit dalam laporan keuangan. Perbedaan waktu ini disebut audit delay. Semakin lama auditor menyelesaikan pekerjaan auditnya, maka semakin lama pula audit delay. Seperti yang dikutip dari investasi.kontan.co.id "Ini dia 49 emiten yang kena sanksi BEI", Akibat mangkir dari kewajibannya dalam menyerahkan laporan keuangan tahunan audit 2013, Bursa Efek Indonesia (BEI) menjatuhkan sanksi kepada sejumlah emiten. Sanksi yang diberikan merupakan sanksi tertulis I. Hal ini lantaran, beberapa perusahaan tercatat melebihi batas waktu toleransi penyampaian laporan keuangan. Informasi saja, laporan keuangan audit 2013 harus sudah disampaikan paling lambat 31 Maret 2014. Bila, emiten telat menyampaikan laporan keuangan sampai 30 hari kalender terhitung sejak batas akhir seharusnya, maka BEI akan menjatuhkan sanksi tertulis I. Bila pada hari kalender ke31 hingga ke-60 belum juga menyampaikan, maka sanksi tertulis II akan melayang. Sanksi ini disertai dengan denda sebesar Rp 50 juta.Selanjutnya, jika pada hari kalender ke-61 hingga ke-90, perseroan masih bandel, maka bursa akan kenakan peringatan tertulis III plus denda Rp 150 juta.Otoritas BEI telah mengenakan peringatan tertulis I kepada 49 emiten yang dinyatakan terlambat menyampaikan laporan keuangan yang telah diaudit tahun 2013. Dari kasus tersebut terlihat pentingnya jangka waktu penyelesaian audit atas laporan keuangan, sebagai faktor yang mempengaruhi ketepatan waktu penyampaian laporan keuangan sekaligus nilai informatif laporan keuangan bagi para pengguna laporan keuangan.

Ashton et al. (dalam Dwi, 2015) menjabarkan bahwa faktor-faktor yang dapat mempengaruhi ketepatan waktu dalam penyelesaian penyajian laporan keuangan (audit delay) pada suatu perusahaan sangat beragam, antara lain faktor internal dan eksternal. Faktor-faktor internal audit delay antara lain total pendapatan, tipe industri, kompleksitas laporan keuangan, kompleksitas data elektronik, laba/rugi dilihat dari total aset, umur perusahaan, pospos luar biasa, laba/rugi, kompleksitas operasi perusahaan dan ukuran perusahaan, sedangkan faktor eksternal yang mempengaruhi audit delay yaitu opini audit, reputasi auditor, dan kualitas auditor.

\section{KAJIAN TEORI \\ Laporan Keuangan}

Laporan keuangan merupakan suatu instrumen yang penting dan sangat bermanfaat dalam sebuah perusahaan. Laporan keuangan merupakan bagian dari proses pelaporan keuangan. Pelaporan keuangan merupakan salah satu sumber informasi yang mengkomunikasikan keadaan keuangan dari hasil operasi perusahaan dalam periode tertentu kepada pihak-pihak yang berkepentingan sehingga manajemen mendapatkan informasi yang bermanfaat (Kartika, 2009). Menurut PSAK No.1, par.10, laporan keuangan harus menyajikan secara wajar posisi keuangan, kinerja keuangan, perubahan ekuitas, dan arus kas perusahaan dengan menerapkan PSAK secara benar disertai pengungkapan yang diharuskan PSAK dalam catatan atas laporan keuangan. Informasi lain tetap disajikan untuk menghasilkan penyajian yang wajar 
walaupun pengungkapan tersebut tidak diharuskan oleh standar akuntansi.

\section{Audit dan Standar Auditing}

Arens, 1995 (dalam Kartika, 2009) memaparkan bahwa tujuan audit secara umum atas laporan keuangan adalah untuk menyatakan pendapat atas kewajaran dalam semua hal yang material, posisi keuangan, hasil usaha dan arus kas yang sesuai dengan prinsip akuntansi berlaku umum di Indonesia. Kewajaran laporan keuangan dinilai berdasarkan asersi yang terkandung dalam setiap unsur yang disajikan dalam laporan keuangan. Asersi adalah pernyataan manajemen yang terkandung dalam komponen laporan keuangan. Standar auditing merupakan pedoman bagi auditor dalam menjalankan tanggung jawab profesionalnya (Rachmawati, 2008). Dunil (2005:106) mengemukakan bahwa Ikatan Akuntan Indonesia (IAI) menetapkan sepuluh standar dalam pekerjaan audit yang disebut sebagai SAI-IAI (Standar Auditing yang Ditetapkan Ikatan Akuntan Indonesia).

\section{Audit Delay}

Aryati dan Theresia, 2005 (dalam Puspitasari dan Nurmala, 2012) mendefinisikan audit delay sebagai rentang waktu penyelesaian pelaksanaan audit laporan keuangan tahunan yang diukur berdasarkan lamanya hari yang dibutuhkan untuk memperoleh laporan auditor independen atas audit laporan keuangan tahunan perusahaan, terhitung sejak tanggal tutup tahun buku perusahaan, yaitu per 31 Desember sampai tanggal tertera pada laporan auditor independen. Menurut Rachmawati (2008) audit delay adalah rentang waktu penyelesaian audit laporan keuangan tahunan, diukur berdasarkan lamanya hari yang dibutuhkan untuk memperoleh laporan auditor independen atas audit laporan keuangan tahunan perusahaan, sejak tanggal tahun tutup buku perusahaan sampai tanggal yang tertera pada laporan auditor independen. Ketepatan waktu penyusunan atau pelaporan suatu laporan keuangan perusahaan dapat berpengaruh pada nilai laporan keuangan tersebut. Semakin panjang audit delay, maka semakin lama auditor dalam menyelesaikan pekerjaan auditnya. Audit delay atau yang dikenal juga sebagai audit report lag inilah yang dapat mempengaruhi ketepatan informasi yang dipublikasikan, sehingga akan berpengaruh terhadap tingkat ketidakpastian keputusan yang berdasarkan informasi yang dipublikasikan (Kartika, 2009).

Faktor-Faktor yang Mempengaruhi Audit Delay

Audit Delay dipengaruhi oleh banyak faktor, yaitu faktor internal dan faktor eksternal. Penelitian-penelitian yang telah dilakukan sebelumya menguji beberapa faktor internal dan faktor eksternal yang mempengaruhi audit delay, antara lain DER, ukuran perusahaan, laba perusahaan, opini audit, ukuran Kantor Akuntan Publik, umur perusahaan, kompleksitas operasi perusahaan dan lain sebagainya. Hasil dari setiap penelitian sering kali menunjukkan hasil yang berbeda-bada. Kemungkinan hal tersebut dikarenakan beberapa hal, seperti perbedaan variabel yang diteliti, perbedaan sampel yan diteliti ataupun perbedaan periode pengamatan. Dalam penelitian ini, peneliti akan menguji kembali beberapa faktor yang mempengaruhi audit delay yaitu ukuran perusahaan, DER, opini audit, dan ukuran Kantor Akuntan Publik.

\section{Ukuran Perusahaan}

Almilia dan Setiady, 2006 (dalam Perina, 2009) memaparkan ukuran perusahaan dapat menunjukkan seberapa besar informasi yang terdapat didalamnya, sekaligus mencerminkan kesadaran dari pihak manajemen mengenai pentingnya informasi, baik bagi pihak internal maupun eksternal perusahaan.

Dyer dan McHugh, 1975 (dalam Rachmawati, 2008) menyatakan bahwa manajemen perusahaan besar memiliki dorongan untuk mengurangi penundaan audit (Audit Delay) dan penundaan laporan keuangan yang disebabkan oleh karena perusahaan besar senantiasa diawasi secara 
ketat oleh para investor, asoisasi perdagangan dan agen regulator.

\section{DER}

Debt to Equity Ratio atau yang umum disingkat dengan DER merupakan rasio keuangan yang membandingkan antara kewajiban dengan ekuitas. Perina (2009) mengemukakan semakin tinggi DER, maka semakin besar pula perusahaan menggunakan modal dari kreditor. Hal tersebut dikarenakan perusahaan dengan kewajiban yang besar diawasi dan dimonitor oleh kreditor sehingga akan memberikan tekanan kepada perusahaan untuk mempublikasi laporan keuangan auditan lebih cepat untuk meyakinkan kembali para pemilik modal yang pada dasarnya menginginkan mengurangi tingkat resiko dalam pengembalian modal mereka. Hal tersebut yang membuat audit delay menjadi lebih singkat.

\section{Opini Audit}

Opini auditor adalah pendapat yang diberikan auditor atas laporan keuangan sebagai hasil akhir dari proses audit. Auditor sebagai pihak yang independen di dalam pemeriksaan laporan keuangan suatu perusahaan, akan memberikan pendapat atas kewajaran laporan keuangan yang diauditnya (Kartika, 2011). Menurut SPAP (Standar Profesional Akuntan publik), ada lima tipe pendapat laporan audit yang diterbitkan oleh auditor, yaitu: a) Pendapat wajar tanpa pengecualian, b) Bahasa penjelasan ditambah laporan auditor bentuk baku, c) Pendapat wajar dengan pengecualian, d) Pendapat tidak wajar, e) Pernyataan tidak memberikan pendapat.

\section{Ukuran Kantor Akuntan Publik}

Menurut Rolinda (dalam Febrianty, 2011) Kantor Akuntan Publik internasional atau yang di kenal dengan the Big Four dianggap dapat melaksanakan auditnya secara efisien dan memiliki jadwal waktu yang lebih tinggi untuk menyelesaikan audit tepat pada waktunya. Waktu audit yang lebih cepat adalah cara bagi Kantor Akuntan Publik besar untuk mempertahankan reputasinya, karena jika tidak menyelesaikan audit dengan cepat maka untuk tahun yang akan datang mereka akan kehilangan kliennya. Besarnya ukuran Kantor Akuntan Publik (KAP) diperlihatkan oleh tingginya kualitas yang dihasilkan dari jasanya yang selanjutnya akan berpengaruh pada jangka waktu penyelesaian audit.

\section{Hipotesis}

a) Hubungan antara Ukuran Perusahaan terhadap Audit Delay Hasil penelitian yang dilakukan oleh Puspitasari dan Nurmala (2012 menyatakan bahwa ukuran perusahaan mempunyai pengaruh positif dan signifikan terhadap audit delay. Sejalan dengan penelitian Puspitasari dan Nurmala (2012), Rachmawati (2008) yang menyebutkan bahwa ukuran perusahaan mempunyai pengaruh positif dan signifikan terhadap audit delay, yang artinya semakin besar ukuran perusahaan maka semakin lama pula audit delay. Hasil penelitian ini tidak sejalan dengan penelitian yang dilakukan oleh Nur dan Anisykurlillah (2014) yang menyebutkan bahwa ukuran perusahaan (size) tidak berpengaruh secara signifikan terhadap audit delay. Maka hipotesis yang akan di uji adalah $\mathrm{H}_{1}$ : Ukuran perusahaan berpengaruh terhadap audit delay.

b) Hubungan antara DER terhadap Audit Delay

Debt to Equity Ratio atau yang umum disingkat dengan DER merupakan rasio keuangan yang membandingkan antara kewajiban dengan ekuitas. Perina (2009) mengemukakan semakin tinggi DER, maka semakin besar pula perusahaan menggunakan modal dari kreditor. Menurut Eka 
(2014) yang menyatakan bahwa DER berpengaruh signifikan terhadap audit delay. Hasil berbeda diungkapkan oleh Kennedy, Eragbhe, dan Jude (2012) yang menyebutkan bahwa DER tidak memiliki pengaruh terhadap audit delay. Maka hipotesis yang akan di uji adalah $\mathrm{H}_{2}$ : DER berpengaruh terhadap audit delay.

c) Hubungan antara Opini Audit terhadap Audit Delay

Penelitian Kusumawardani (2013) dengan judul Faktor-Faktor Yang Mempengaruhi Audit Delay Pada Perusahaan Manufaktur menyebutkan bahwa opini auditor berpengaruh terhadap audit delay, ini berarti dengan opini selain unqualified menuntut auditor lebih berhati-hati dalam melakukan prosedur auditnya sehingga waktu pelaporan keuangannya lebih lama. Berbeda dengan penelitian Kartika (2011) dengan judul Faktor Faktor Yang Mempengaruhi Audit Delay Pada Perusahaan Manufaktur Yang Terdaftar Di BEI menyatakan bahwa tidak ada pengaruh opini audit terhadap audit delay. Maka hipotesis yang akan di uji adalah $\mathrm{H}_{3}$ : Opini audit berpengaruh terhadap audit delay

d) Hubungan antara ukuran KAP terhadap Audit Delay

Perusahaan yang diaudit oleh KAP yang termasuk the Big Four cenderung lebih cepat menyelesaikan tugas audit bila dibandingkan dengan KAP Non Big Four KAP Big Four umumnya memiliki sumber daya yang lebih besar (kompetensi, keahlian, dan kemampuan auditot; fasilitas; sistem dan prosedur pengauditan yang digunakan, dan lain-lain) dibandingkan dengan $K A P$ Non Big Four sehingga KAP Big
Four akan dapat menyelesaikan pekerjaan audit dengan lebih efektif dan efisien (Febrianty, 2011). Waktu audit yang cepat merupakan salah satu cara KAP dengan kualitas tinggi untuk mempertahankan reputasi mereka. Maka hipotesis yang akan di uji adalah $\mathrm{H}_{4}$ : Ukuran KAP berpengaruh terhadap audit delay

e) Hubungan antara ukuran perusahaan, DER, laba perusahaan, opini audit, dan ukuran KAP terhadap Audit Delay. Penelitian Nur dan Anisykurlillah (2014) menyatakan bahwa secara simultan, variabel size, laba, opini audit, dan ukuran KAP berpengaruh signifikan terhadap audit delay. Dalam penelitian Eka (2014) menunjukkan secara bersama-sama variabel ukuran perusahaan, solvabilitas, laba/rugi perusahaan, dan ukuran KAP berpengaruh secara signifikan terhadap audit delay. Maka hipotesis yang akan diuji adalah $\mathrm{H}_{5}$ : Ukuran perusahaan, DER, opini audit, dan ukuran KAP berpengaruh terhadap Audit Delay.

\section{METODE PENELITIAN}

Penelitian ini dilakukan dengan melakukan pendekatan studi kasus pada 49 perusahaan yang terdaftar terdaftar di Bursa Efek Indonesia (BEI) dan mendapat sanksi BEI pada tahun 2013, dimana data yang digunakan dalam penelitian ini adalah data sekunder yang diperoleh dari website www.idx.co.id Waktu yang dibutuhkan dalam penelitian adalah bulan Maret hingga September 2016. Dalam penelitian ini variabel yang di gunakan adalah variabel dependen dan variabel independen.

Variabel Dependen (dependent variable)

Variabel dependen yaitu yang dipengaruhi oleh variabel lain atau bisa disebut variabel terikat. Dalam penelitian variabel dependen yang digunakan 
adalahAudit Delay, yaitulamanya waktu penyelesaian audit yang diukurdari tanggal penutupan tahun buku hingga tanggal diterbitkannya laporan.Variabel ini diukur secara kuantitatif dalam jumlah hari.Audit Delay di rumuskan dengan menggunakan rumus (Malinda, 2015:51) :

Audit Delay $=$ Tanggal Laporan

Audit - Tanggal Laporan keuangan

Variabel Independen (independent variable)

Variabel independen atau variabel bebas yaitu variabel yang mempengaruhi variabel lain, variabel independen yang digunakan dalam penelitian ini adalah:

\section{Ukuran Perusahaan (Size)}

Ukuran perusahaan adalah besar kecilnya suatu perusahaan yang diukur dengan menggunakan total aset, baik aset lancar maupun aset tidak lancar yang dimiliki oleh perusahaan. Total aktiva dirumuskan dengan menggunkan rumus (Frildawati, 2009:82) :

\section{DER}

$$
\text { Size }=L n \text { total aktiva }
$$

Debt to Equity Ratio (DER) menunjukkan kemampuan modal perusahaan untuk memenuhi seluruh kewajibannya. Menurut Dwi Prastawa dalam Eka (2014), pengukuran variabel tersebut menggunakan rumus berikut :

\section{Opini Audit}

\section{DER $=$ Total Utang $:$ Total Modal}

Opini auditor adalah pendapat yang diberikan auditor atas laporan keuangan sebagai hasil akhir dari proses audit.Opini audit dalam penelitian ini diukur dengan cara membagi opini audit untuk perusahaan dalam dua kelompok yaitu perusahaan yang mendapat jenis opini unqualified dan perusahan yang mendapat jenis opini selain unqualified, dengan menggunakan pengukuran dummy variabel sebagai berikut :

1 : untuk perusahan yang mendapat jenis opini unqualified.

0 : untuk perusahan yang mendapat jenis opini selain unqualified.

4. Ukuran Kantor Akuntan Publik

Perusahaan

dalam

menyampaikan suatu laporan atau informasi akan kinerja perusahaan kepada publik agar akurat dan terpercaya diminta untuk menggunakan jasa KAP. Dan untuk meningkatkan kredibilitas dari laporan itu, perusahaan menggunakan jasa KAP yang mempunyai reputasi atau nama baik. Hal ini biasanya ditunjukkan dengan KAP yang berafiliasi dengan KAP besar yang berlaku universal yang dikenal dengan Big Four Worldwide Accounting Firm atau Big Four (Hilmi dan Ali, 2008). Ukuran KAP dalam penelitian ini diukur dengan cara membagi KAP dalam dua kelompok yaitu KAP yang bermitra dengan KAP Big Fourdan KAP yang tidak bermitra dengan KAP Big Four, dengan menggunakan pengukuran dummy variabel sebagai berikut :

1 : untuk KAP yang bermitra dengan KAP Big Four.

0 : untuk KAP yang tidak bermitra dengan KAP Big Four.

\section{Teknik Pengumpulan Data}

Pengumpulan data yang digunakan dalam penelitian ini dengan cara mengumpulkan, mencatat, dan mengkaji data sekunder yang berupa laporan keuangan perusahaan, laporan auditor, maupun laporan lain yang bersangkutan dengan penelitian.Laporan tersebut dapat diperoleh melalui website Bursa Efek Indonesia (www.idx.co.id). 


\section{Teknik Analisis Data}

Langkah-langkah analisis yang digunakan peneliti diuraikan sebagai berikut: a) Statistik Deskriptif, b) Uji Asumsi Klasik, c) Pengujian Hipotesis.

\section{HASIL DAN PEMBAHASAN Statistik Deskriptif}

Digunakan untuk menggambarkan fenomena atau karakteristik data. Analisis Analisis deskriptif memberikan gambaran atau deskripsi suatu data yang dilihat dari niali rata-rata, standar devisiasi, varian, maksimum, minimum. Berikut adalah hasil dari statistik deskritif dari penelitian ini:

Tabel 1. Hasil Uji Statistik Deskriptif

\begin{tabular}{lrrrrr}
\hline & \multicolumn{1}{c}{ N } & \multicolumn{1}{c}{ Min } & Max & \multicolumn{1}{c}{ Mean } & Std. Deviation \\
\hline Audit_Delay & 64 & 60 & 121 & 87.62 & 10.899 \\
Size & 64 & 16 & 29 & 22.55 & 4.230 \\
DER & 64 & -45 & 71 & 2.03 & 12.408 \\
Opini_Audit & 64 & 0 & 1 & .27 & .445 \\
Ukuran_KAP & 64 & 0 & 1 & .33 & .473 \\
Valid N & 64 & & & & \\
(listwise) & & & & & \\
\hline
\end{tabular}

Sumber: Data diolah 2016

Berdasarkan tabel di atas dengan sampel 64 unit, dapat dijelaskan bahwa audit delay memiliki mean sebesar 87,62 hari artinya dari seluruh perusahaan yang digunakan sampel memiliki audit delay 87,62 hari. Standar deviasi pada audit delay 10,899 hari. Standar deviasi digunakan untuk menilai penyebaran (dispersi) rata-rata dari sampel, berarti penyebaran rata-rata sampel tentang audit delay sebesar 10,899 hari.Nilai minimum sebesar 60 hari artinya bahwa dari seluruh nilai audit delay nilai terendah sebesar 60 hari. Nilai maksimum sebesar 121 hari, artinya bahwa dari seluruh nilai audit delay perusahaan yang dijadikan sampel penelitian memiliki nilai terbesar sebesar 121 hari.

Variabel ukuran perusahaan (size) memiliki nilai mean sebesar 22,55 artinya bahwa dari seluruh nilai ukuran perusahaan rata-rata mempunyai nilai sebesar 22,55.
Standar deviasi pada ukuran perusahaan sebesar 4,230. Standar deviasi digunakan untuk menilai penyebaran (dispersi) rata-rata dari sampel, sehingga berarti penyebaran rata-rata sampel tentang ukuran perusahaan sebesar 4,230. Nilai minimum sebesar 16 artinya bahwa dari seluruh nilai ukuran perusahaan nilai terendah sebesar 16 . Nilai maksimum sebesar 29 artinya bahwa dari seluruh nilai ukuran perusahaan yang dijadikan sampel penelitian memiliki nilai terbesar sebesar 29.

Pada variabel DER memiliki nilai mean sebesar 2,03 artinya bahwa dari seluruh nilai DER rata-rata mempunyai nilai sebesar 2,03. Standar deviasi pada DER sebesar 12,408. Standar deviasi digunakan untuk menilai penyebaran (dispersi) rata-rata dari sampel, sehingga penyebaran rata-rata sampel tentang DER sebesar 12,408. Nilai minimum sebesar -45 artinya bahwa dari seluruh nilai DER nilai terendah sebesar -45 . Nilai maksimum sebesar 71 artinya bahwa dari seluruh nilai DER perusahaan yang dijadikan sampel penelitian memiliki nilai terbesar sebesar 71 .

Pada variabel opini auditor memiliki nilai mean sebesar 0,27 artinya bahwa dari seluruh nilai opini auditor rata-rata mempunyai nilai sebesar 0,27. Standar deviasi pada opini auditor sebesar 0,445. Standar deviasi digunakan untuk menilai penyebaran (dispersi) rata-rata dari sampel, sehingga berarti penyebaran rata-rata sampel tentang opini auditor sebesar 0,445. Nilai minimum sebesar 0 artinya bahwa dari seluruh nilai opini auditor nilai terendah sebesar 0 . Nilai maksimum sebesar 1 artinya bahwa dari seluruh nilai opini auditor perusahaan yang dijadikan sampel penelitian memiliki nilai terbesar sebesar 1 .

Pada variabel ukuran KAP memiliki nilai mean sebesar 0,33 artinya bahwa dari seluruh nilaiukuran KAP rata-rata mempunyai nilai sebesar 0,33. Standar deviasi pada ukuran KAP sebesar 0,473. 
Standar deviasi digunakan untuk menilai penyebaran (dispersi) rata-rata dari sampel, sehingga berarti penyebaran rata-rata sampel tentang kualitas auditor sebesar 0,473. Nilai minimum sebesar 0 artinya bahwa dari seluruh nilai ukuran KAP memiliki nilai terendah sebesar 0. Nilai maksimum sebesar 1 artinya bahwa dari seluruh nilai ukuran KAP yang sampel penelitian memiliki nilai terbesar sebesar 1.

\section{Hasil Uji Asumsi Klasik}

Tabel 2. Hasil Uji Normalitas

\begin{tabular}{llr}
\hline \multicolumn{2}{c}{ One-Sample Kolmogorov-Smirnov Test } & $\begin{array}{c}\text { Unstandardized } \\
\text { Residual }\end{array}$ \\
\hline $\mathrm{N}$ & Mean & 64 \\
Normal Parameters ${ }^{\mathrm{a}, \mathrm{b}}$ & Std. Deviation & .0000000 \\
& Absolute & 10.73235633 \\
Most Extreme Differences & Positive & .154 \\
& Negative & .154 \\
& & -.108 \\
Kolmogorov-Smirnov Z & & 1.234 \\
Asymp. Sig. (2-tailed) & & .095 \\
\hline
\end{tabular}

Sumber : Data diolah 2016

Hasil uji normalitas pada tabel 4.2 dengan menggunakan uji KolmogorofSemirnof dapat diketahui bahwa residual menyebar secara normal karena nilai probabilitas signifikansinya sebesar 0,095> 0,05 sehingga dapat disimpulkan data telah terdistribusi dengan normal.

Tabel 3. Hasil Uji Multikolinieritas Coefficients $^{\mathrm{a}}$

Collinearity Statistics

\begin{tabular}{llll} 
Model & \multicolumn{2}{c}{ Tolerance } & VIF \\
\hline $1 \quad$ (Constant) & & \\
& Size & .844 & 1.184 \\
& DER & .965 & 1.036 \\
& Opini_Audit & .741 & 1.350 \\
& Ukuran_KAP & .722 & 1.384 \\
\hline
\end{tabular}

Sumber : Data diolah 2016

Hasil perhitungan nilai Tolerance dan VIF menunjukkan tidak ada variabel independen yang memiliki nilai Tolerance > 0,10 atau VIF $<10$, nilai tolerance pada variabel size $=0,844, \mathrm{DER}=0,965$, Opini $=$ 0,741 dan pada variabel ukuran KAP memiliki nilai tolerance sebesar 0,722 sedangkan VIF pada variabel size $=1,184$,
DER $=1,036$, Opini $=1,350$ dan pada ukuran KAP sebesar 1,384. Jadi, dapat disimpulkan bahwa tidak ada multikoliniearitas antar variabel independen dalam model regresi.

\section{Gambar 1. Hasil Uji Heterokesdatisitas}

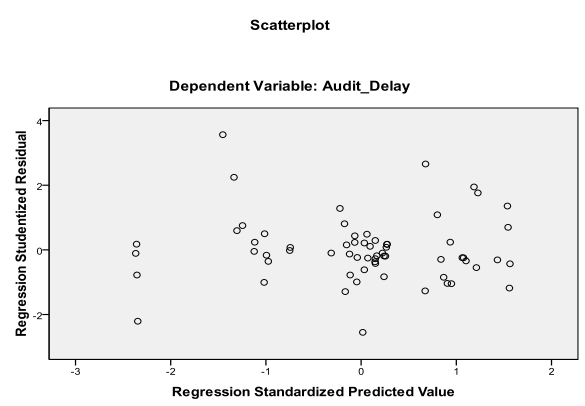

Dari grafik Scatterplot diatas terlihat bahwa titik-titik menyebar secara acak atau titik-titik tidak membentuk pola yang jelas serta tersebar baik di atas maupun di bawah angka 0 pada sumbu $\mathrm{Y}$. Hal ini dapat di simpulkan bahwa tidak terjadi heterokedaktisitas.

\section{Tabel 4. Hasil Uji Autokorelasi}

\begin{tabular}{lr}
\hline & Runs Test \\
& Unstandardized Residual \\
\hline Test Value $^{\mathrm{a}}$ & -1.26551 \\
Cases $<$ Test Value & 32 \\
Cases $>=$ Test Value & 32 \\
Total Cases & 64 \\
Number of Runs & 30 \\
Z & -.756 \\
Asymp. Sig. (2-tailed) & .450 \\
\hline
\end{tabular}

Sumber : Data diolah 2016

Berdasarkan tabel 4.4 dapat dilihat bahwa hasil Run Test menunjukkan nilai Asymp. Sig. atau nilai probabilitasnya sebesar 0,450. Nilai tersebut lebih besar dari 0,05. Dengan demikian tidak terjadi autokorelasi dalam persamaan regresi yang digunakan. 


\section{Analisis Regresi Berganda}

Tabel 5. Hasil Analisis Regresi Linier

\begin{tabular}{llrr}
\hline \multicolumn{3}{c}{ Coefficients $^{\mathbf{a}}$} \\
Model & & \multicolumn{2}{c}{ Unstandardized Coefficients $^{-}$} \\
1 & B & Std. Error \\
& (Constant) & 95.134 & 8.438 \\
& Size & -.278 & .359 \\
& DER & .000 & .115 \\
& Opini_Audit & -1.878 & 3.647 \\
& Ukuran_KAP & -2.290 & 3.474 \\
\hline
\end{tabular}

Sumber : Data diolah 2016

Berdasarkan tabel di atas, maka persamaan regresi yang di dapat adalah sebagai berikut:

\section{$\mathrm{Y}=\mathbf{9 5 , 1 3 4}-\mathbf{0 , 2 7 8}($ Size $)+0,000$ (DER) - 1,878 (Opini)- 2,290 (Ukuran KAP)+e}

Konstanta $=95,134$, artinya jika variabel size, DER, opini audit dan ukuran KAP dianggap sama dengan nol, maka variabel AuditDelayakan sebesar95,134. Koefisien size $=-0,278$, artinya jika variabelsize mengalami kenaikan sebesar satu poin, sementara DER, opini audit dan ukuran KAP dianggap tetap, maka akan menyebabkan penurunan Audit Delaysebesar0,278. Koefisien $\mathrm{DER}=0,000$, artinya jika variabel DER mengalami kenaikan satu poin sementara variabel size, opini auditor, dan ukuran KAP tetap, maka akan menyebabkan penurunanAudit Delay sebesar 0,000. Koefisien opini audit $=-1,878$, artinya jika variabel opini auditor mendapatkan opini unqualified (mendapatkan kode 1), sementara variabel size, DER dan ukuran KAP tetap maka akan menyebabkan penurunan Audit Delaysebesar1,878. Koefisien ukuran KAP $=-2,290$, artinya variabel ukuran KAP termasuk didalam kategori Big Four (mendapatkan kode 1), sementara variabel size, DER dan Opini audit tetap, maka akan menyebabkan penurunan Audit Delay sebesar 2,290.

\section{Uji Hipotesis}

Tabel 6. Hasil Uji t

$$
\text { Coefficients }^{\mathbf{a}}
$$

Unstandardized Standardized

Coefficients Coefficients

\begin{tabular}{llrrrrr} 
Model & & B & Std. Error & Beta & $\mathrm{t}$ & \multicolumn{1}{l}{ Sig. } \\
\hline 1 & (Constant) & 95.13 & 8.438 & & 11.274 & .000 \\
& & 4 & & & & \\
& Size & -.2 & .359 & -.108 & -.772 & .443 \\
& & 78 & & & & \\
& DER & .000 & .115 & .000 & -.004 & .997 \\
& Opini_Audit & - & 3.647 & -.077 & -.515 & .608 \\
& & 1.878 & & & & \\
& Ukuran_KAP & - & 3.474 & -.099 & -.659 & .512 \\
& & 2.290 & & & & \\
\hline
\end{tabular}

Sumber : Data diolah 2016

Berdasarkan tabel diatas, maka dapat disimpulkan Variabel size, DER, Opini Audit dan KAP tidak berpengaruh signifikan terhadap audit delay.

Tabel 7. Hasil Uji f

\begin{tabular}{llrrrrr}
\hline \multicolumn{7}{c}{ ANOVA $^{\mathbf{b}}$} \\
Model & & $\begin{array}{c}\text { Sum of } \\
\text { Squares }\end{array}$ & df & Mean & & \\
\hline 1 & Reguare & \multicolumn{1}{c}{ F } & Sig. \\
& Residual & 7256.559 & 59 & 122.993 & & \\
& Total & 7483.000 & 63 & & & \\
\hline
\end{tabular}

Sumber : Data diolah 2016

Berdasarkan tabel 7 nilai $\mathrm{F}=0,460<$ 2,52 dan sig $=0,765>0,05$ ini berarti variabel independen ukuran perusahaan (size), DER, opini auditor dan ukuran KAP secara simultan tidak berpengaruh terhadap variabel dependen audit delay.

\section{Koefisien Determinasi}

Tabel 8. Hasil Uji Determinasi

\begin{tabular}{lccccc}
\hline \multicolumn{5}{c}{ Model Summary $^{\mathbf{b}}$} \\
Model & $\mathrm{R}$ & $\begin{array}{c}\mathrm{R} \\
\text { Square }\end{array}$ & Adjusted R Square & $\begin{array}{c}\text { Std. Error of } \\
\text { the Estimate }\end{array}$ & $\begin{array}{c}\text { Durbin- } \\
\text { Watson }\end{array}$ \\
\hline 1 & $.174^{\mathrm{a}}$ & .030 & -.035 & 11.090 & 1.436 \\
\hline \multicolumn{5}{c}{ Sumber : Data diolah 2016 }
\end{tabular}

Berdasarkan tabel 4.8 nilai Adjusted $\mathrm{R}^{2}$ $=0,030$. Variabel bebas ukuran perusahaan (Size), opini auditor, dan ukuran KAP secara bersama-sama mempengaruhi variabel dependen audit delay sebesar 3,0\% dan sisanya sebesar 97,0\% dipengaruhi oleh variabel lain yang tidak masuk dalam penelitian ini. 


\section{KESIMPULAN}

Berdasarkan analisis data dan pembahasan yang telah dilakukan dapat diambil kesimpulan sebagai berikut:

1. Ukuran perusahaan (size) tidak berpengaruh signifikan terhadap variabel dependen audit delay.

2. DER tidak berpengaruh signifikan terhadap variabel dependen audit delay.

3. Opini audit tidak berpengaruh signifikan terhadap variabel dependen audit delay.

4. Ukuran KAP tidak berpengaruh signifikan terhadap variabel dependen audit delay.

5. Ukuran perusahaan (size), DER, opini auditor dan ukuran KAP secara simultan tidak berpengaruh terhadap variabel dependen audit delay.

\section{DAFTAR PUSTAKA}

Agus, M Sudrajat. 2013. Pengaruh Corporate Governance Perception Index Terhadap Kinerja Perusahaan Yang Terdaftar Di Bursa Efek Indonesia (Peringkat 20 Besar Cgpi Tahun 2008- 2011). Tesis. Fakultas Ekonomi Universitas Sebelas Maret Surakaarta

Amirullah. 2013. Metodologi Penelitian Manajemen:Disertai Contoh Judul Penelitian dan Proposal. Malang : Bayumedia Publishing.

Dunil, Z. 2005. Bank Auditing : Risk Based Audit Dalam Pemeriksaan Perkreditan Bank Umum. Jakarta : PT. Indeks Kelompok Gramedia.

Dewi, Oviek Saputri. 2012. Analisis FaktorFaktor Yang Mempengaruhi Audit Delay (Studi Empiris Pada Perusahaan-Perusahaan Yang Terdaftar Di Bursa Efek Indonesia). Fakultas Ekonomi Universitas Diponegoro Semarang.

Dwi, Malinda Apriliane. 2015. Analisis Faktor-Faktor yang Mempengaruhi Audit Delay (Studi Empiris Pada Perusahaan Pertambangan yang
Terdaftar di Bursa Efek Indonesia Tahun 2008 - 2013). Skripsi. Fakultas Ekonomi Universitas Negeri Yogyakarta.

Eka, Kristanti A.S. 2014. Pengaruh Total Asset. ROA, DER, Ukuran KAP, dan Laba Atau Rugi Perusahaan Terhadap Audit Delay Pada Perusahaan Manufaktur yang Terdapat di Bursa Efek Indonesia Periode 2011-2012. Economics \& Business Research Festival. Vol 3/November 2014.

Febrianty. 2011. Faktor-Faktor yang Berpengaruh Terhadap Audit Delay Perusahaan Sektor Perdagangan yang Terdaftar di Bei Periode 20072009. Jurnal Ekonomi Dan Informasi Akuntansi. VOL. 1/NO. 3/September 2011:294-320.

Frildawati, Devi. 2009. Analisis Faktorfaktor yang Mempengaruhi Audit Delay (Studi Khasus pada Perusahaan di Bursa Efek Indonesia). Skripsi. Fakultas Ekonomi dan Ilmu Sosial Universitas Islam Negeri syarif Hidayatullah Jakarta.

Ghozali, Imam. 2011. Aplikasi Analisis Multivariate Dengan Program IBM SPSS19. Semarang : Badan Penerbit Universitas Diponegoro.

Hilmi, Utari dan Syaiful Ali. 2008. Analisis Faktor-faktor yang Mempengaruhi Ketepatan Waktu Penyampaian Laporan Keuangan : Studi Empiris Pada Perusahaan-Perusahaan yang Terdaftar Di BEJ Periode 20042006. Simposium Nasional Akuntansi XI, Pontianak.

https://staff.blog.ui.ac.id/martani/files/2011/0 4/ED-PSAK-1.pdf

Januar, Meylisa Iskandar dan Estralita Trisnawati .2010. Faktor-faktor yang Mempengaruhi Audit Report Lag Pada Perusahaan yang Terdaftar di 
BEI. Jurnal bisnis dan Akuntansi.Volume 12,No. 13,Desember 2010.

Kartika, Andi. 2011. Faktor-Faktor Yang Mempengaruhi Audit Delay Pada Perusahaan Manufaktur yang Terdaftar di BEI. Dinamika Keuangan dan Perbankan. Vol. 3/ No. 2/Nopember $2011: 152$ - 171.

Kennedy, Prince Modugu, Emmanuel Eragbhe, dan Ohiorenuan Jude Ikhatua. 2012. Determinants of Audit Delay in Nigerian Companies : Empericial Edvidence. Research Journal of Finance and Accounting. Vol 3/No. 6/2012.

Kusumawardani, Fitria. 2013. Faktor-Faktor yang Mempengaruhi Audit Delay Pada Perusahaan Manufaktur. Accounting Analysis Journal. Vol. 2/ No. 1/ Februari 2013 : 52-58.

Nur, Alifian Aditya dan Indah Anisykurlillah. 2014. Faktor-Faktor yang Berpengaruh Terhadap Audit Delay. Accounting Analysis Journal. Vol. 3/No. 3/2014.

Perina, Kartika Simbolon. 2009. Analisis Faktor-Faktor yang Mempengaruhi Audit Delay Pada Perusahaan yang Terdaftar di Bursa Efek Indonesia.
Skripsi. Fakultas Ekonomi Universitas Sumatera Utara Medan.

Puspitasari, Elen dan Anggraeni Nurmala Sari. 2012. Pengaruh Karakteristik Perusahaan Terhadap Lamanya Waktu Penyelesaian Audit (Audit Delay) Pada Perusahaan Manufaktur yang Terdaftar di Bursa Efek Indonesia. Jurnal Akuntansi \& Auditing. Volume 9/No.1/November 2012 : 1-96.

Rachmawati, Sistya. 2008. Pengaruh Faktor Internal dan Eksternal Perusahaan Terhadap Audit Delay dan Timeliness. Jurnal Akuntansi Dan Keuangan. Vol. 10/No. 1/Mei 2008 : $1-10$.

Sahruddin, Muhammad. 2012. Analisis Faktor-Faktor Yang Mempengaruhi Audit Delay Pada Perusahaan Go Publik Di Bursa Efek Indonesia. Jurnal Murni Sadar. Vol 2, No. 2, Agustus 2012.

Widyantari, Ni Putu Dan Made Gede Wirakusuma. 2013. Faktor-Faktor Yang Mempengaruhi Audit Delay. Jurnal. Fakultas Ekonomi Universitas Udayana (Unud), Bali, Indonesia.

www.investasikontan.com

www.bei.com 